\title{
Relationship between Resistance to Barley Yellow Dwarf Virus in Spring Barley and Aphid Feeding Behaviour
}

\author{
O. O. BANWO* and R. HARRINGTON \\ Institute of Arable Crop Research (IACR) - Rothamsted \\ Harpenden, Herts, AL5 2JQ, United Kingdom
}

\begin{abstract}
The feeding period of the grain aphid, Sitobion avenae, an important vector of barley yellow dwarf virus (BYDV), was studied in six varieties of spring barley (Hordeum vulgare L.) in an attempt to explain the resistance mechanisms in some barley varieties to BYDV. There was no significant difference in aphid feeding period between the resistant and susceptible varieties. The mechanisms underlying BYDV resistance do not seem to involve factors related to alterations in the feeding period. Suggestions for future studies are highlighted.
\end{abstract}

Keywords: Barley yellow dwarf virus; feeding period; Sitobion avenae; susceptible; tolerance.

Barley yellow dwarf virus (BYDV) is found world-wide, it has been identified in at least one country in every continent. It is the most widely distributed of all the cereal viruses (Rochow, 1970; Lister and Ranieri, 1995). Economic losses have been associated with BYDV in the U.S.A. (Oswald and Houston, 1953), U.K. (A'Brook, 1974), and New Zealand (Smith, 1993).

At least 25 aphid species have been reported as vectors of BYDV (Plumb, 1977). In the U.K., the grain aphid Sitobion avenae, the rose grain aphid Metopolophium dirhodum and the bird cherry aphid Rhopalosiphum padi are the most important BYDV vectors (A'Brook and Dewar, 1980). In spring-sown cereals $S$. avenae is considered to be the principal source of primary infection to the crop (Plumb, 1977). Little is known regarding aphid feeding as a component of BYDV resistance despite the fact that resistance in cereals is related to aphid activity (Ullman et al., 1988).

It is thought that early sowing reduces aphid colonisation prior to stem elongation and hence decreases damage from virus but even this may not be adequate after very mild winters when aphids begin to fly into the crop early in the season. Application of insecticides to control BYDV in spring-sown cereals has been attempted with little success in the U.K. (Irwin and Thresh, 1990). In order to assess the potential of some fortuitously discovered "resistant"/ "tolerant" varieties, it is essential to understand the mechanism by which such resistance or tolerance is conferred. This study sought to determine whether or not inoculation access feeding period (IAFP), a component of feeding behaviour, is responsible for the apparent BYDV resistance in three varieties of spring barley.

${ }^{*}$ Corresponding author; present address: Department of Crop Science and Production, Sokoine University of Agriculture, P.O. Box 3005, Morogoro, Tanzania (E-mail: banwo@hotmail.com; banwo@suanet.ac.tz) 


\section{Materials and Methods}

\section{The aphid cultures}

Virus-free cultures of $S$. avenae were maintained on barley (cv. Magie) at 18 hour light and 6 hour dark cycle (L 18:D6) at $18{ }^{\circ} \mathrm{C}$. The culture plants were changed weekly and population of aphids was reduced at each plant change in order to avoid overcrowding. Viruliferous cultures of $S$. avenae were started with aphids from the virus-free cultures but were kept in a separate place to avoid contamination of the virus free stocks. Aphids were removed from the culture and placed on oat plants (cv. Dula) infected with the MAV-like isolate of BYDV and kept in a cage in the laboratory at approximately $21^{\circ} \mathrm{C}$. These aphids were removed after 72 hours virus acquisition access period and kept in glass tubes for an overnight starvation period.

\section{The plant materials}

Test plant used in this study were three BYDV "resistant" (Cooper, R1; Optic, R2; and Amber, R3) and three "susceptible" (Alexis, S1; Derkado, S2 and Triumph, S3) varieties of spring barley. Oat (cv. Dula) was used as a control since it is thought to be the most susceptible cereal to BYDV. Ten seeds of each variety were planted in peat jiffy pots placed in plastic trays. One set was used for the four feeding periods (IAFP).

\section{Inoculation of plants with BYDV}

The IAFP used were 6, 12, 24 and 48 hours (Lowles et al., 1996). Sitobion avenae specific isolate of BYDV (the MAV-like isolate) was used in all the experiments. One week old test plants were used since this stage is the most susceptible to the disease and the potential for yield loss is very high (Doodson and Saunders, 1970). The test plants were inoculated with the virus by confining one winged viruliferous $S$. avenae per plant for the required length of time. The aphids were contained in a $2.5 \mathrm{~cm}$ diameter cellulose acetate tube with a netting top which was pushed into the soil around the plant. The aphids were put at the base of the plants by means of a pair of forceps clipped to one of the wings so as to allow the aphids to freely find their own feeding site on the plants. After each IAFP, each aphid was removed and any nymphs killed simply by crushing them to death. The ten plants for each variety/time combination were transferred to a separate glasshouse for spraying to kill any nymphs missed. Pirimicarb (a contact insecticide with some systemic activity) at $0.5 \mathrm{~g}$ a. i. litre ${ }^{-1}$ was used. The plants were then removed to the glasshouse and watered regularly until they were ready for the serological test. In the glasshouse the mean temperature was $21^{\circ} \mathrm{C}$, the maximum $26^{\circ} \mathrm{C}$ and the minimum $16^{\circ} \mathrm{C}$ during the study. In total, 6 replicate runs of the experiment were carried out and a completely randomised block design was used. Two hundred and eighty aphids and two hundred and eighty plants were used per run (i.e. one aphid per plant). The indirect double antibody sandwich ELISA (Lister and Rochow, 1979) was used in testing the plants for the presence of BYDV 21 days after inoculation was carried out. 


\section{Data analysis}

Data were analysed and run on the Rothamsted GENSTAT computer programme. Logistic regression model via the generalised linear model (GLM) was fitted to proportion of plants infected. The effect of time was split into a linear component to see whether proportions changed linearly with time or whether any other relationship could be observed. Overall differences between the six replicate runs were accounted for before fitting treatment terms. Treatment differences were not assessed using conventional chi-square statistics since the Residual Mean Deviance (RMD) was greater than 1. Hence the mean deviances (chi-square) were scaled to RMD to produce approximate $\mathrm{F}$ ratios.

\section{Results}

ELISA test results are summarised in Table 1. There was no significant relationship between;

a) The proportion of plants with virus and inoculation access feeding period (6hr, $12 \mathrm{hr}, 24 \mathrm{hr}$ and 48hr). b) Oats, all the "susceptible" (Alexis, S1; Derkado, S2; and Triumph, S3) combined together as a single entry and all the "resistant" varieties (Cooper, R1; Optic,

Table 1

Accumulated analysis of deviance: proportion of infected plants and feeding periods as shown by ELISA

\begin{tabular}{lcccc}
\hline change & df & deviance & mean deviance & deviance ratio \\
\hline + TIME & 3 & 10.311 & 3.437 & $1.26^{\mathrm{NS}}$ \\
+ F1 & 2 & 6.870 & 3.435 & $1.26^{\mathrm{NS}}$ \\
+ F1. F2 & 2 & 4.58 & 2.293 & $0.84^{\mathrm{NS}}$ \\
+ F1. F2. F3 & 2 & 0.298 & 0.149 & $0.05^{\mathrm{NS}}$ \\
+ TIME . F1 & 6 & 4.523 & 0.754 & $0.28^{\mathrm{NS}}$ \\
+ TIME . F1. F2 & 6 & 3.919 & 0.653 & $0.24^{\mathrm{NS}}$ \\
+ TIME . F1. F2. F3 & 6 & 3.727 & 0.621 & $0.23^{\mathrm{NS}}$ \\
Residual & 140 & 381.539 & 2.725 & \\
Total & 167 & 415.773 & 2.490 & \\
\hline
\end{tabular}

NS $=$ Not statistically significant

TIME = Inoculation access feeding periods $(6 \mathrm{hr}, 12 \mathrm{hr}, 24 \mathrm{hr}$ and $48 \mathrm{hr})$

$\mathrm{F} 1=$ Oats Vs S1 + S2 + S3 Vs R1 + R2 + R3

$\mathrm{F} 2$ = Oats Vs S1 Vs S2 Vs S3 Vs R1 + R2 + R3

F3 = Oats Vs S1 Vs S2 Vs S3 Vs R1 Vs R2 Vs R3

R2; and Amber, R3) also combined together as a single entry. c) Oats, all "susceptible" varieties (Alexis, S1; Derkado, S2; and Triumph, S3) as individual entries and all the "resistant" varieties (Cooper, R1; Optic, R2; and Amber, R3) combined together as a single entry. d) Oats, all the "susceptible" (Alexis, S1; Derkado, S2; and Triumph, S3) and "resistant" (Cooper, R1; Optic, R2; and Amber, R3) varieties as individual entries. 
Also, no significant relationship was also observed between;

a) Inoculation access feeding period, Oats, all the "susceptible" (Alexis, S1; Derkado, S2; and Triumph, S3) combined together as a single entry and all the "resistant" varieties (Cooper, R1; Optic, R2; and Amber, R3) also combined together as a single entry (Fig. 1). b) Inoculation access feeding period, Oats, all "susceptible" varieties (Alexis, S1; Derkado, S2; and Triumph, S3) as individual entries and all the "resistant" varieties (Cooper, R1; Optic, R2; and Amber, R3) combined together as a single entry. c) Inoculation access feeding period, Oats, all the "susceptible" (Alexis, S1; Derkado, S2; and Triumph, S3) and "resistant" (Cooper, R1; Optic, R2; and Amber, R3) varieties as individual entries.

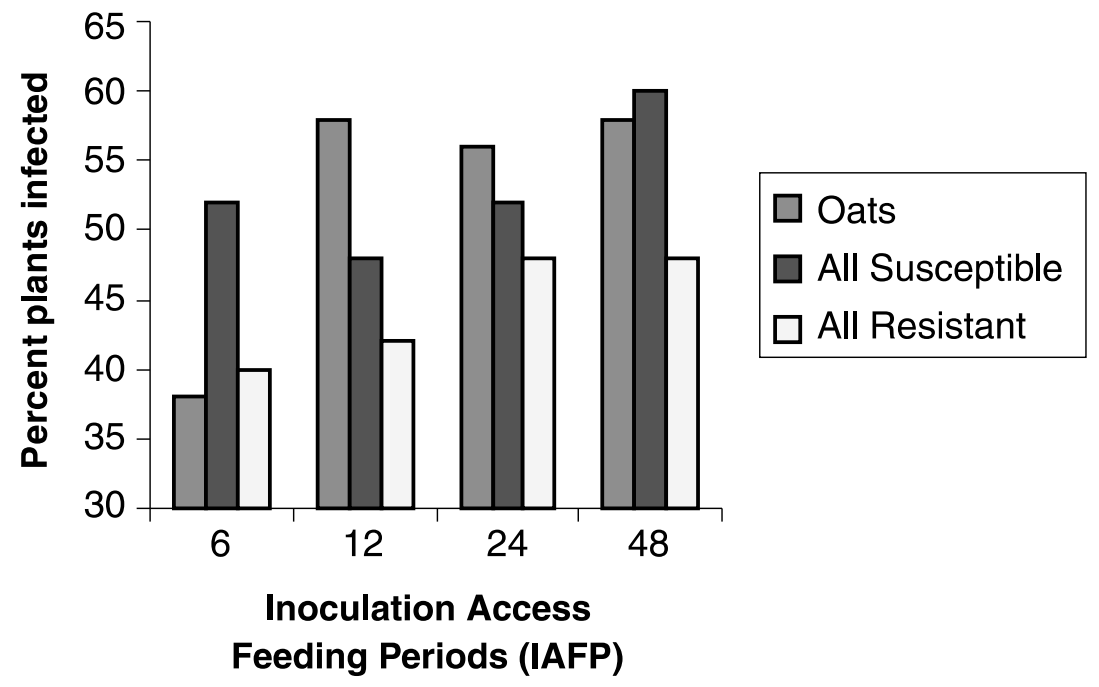

Fig. 1. Proportion of plants infected versus inoculation access feeding periods (Time) in hrs

\section{Discussion}

Reports by Haniotakis and Lange (1974) and Tjallingi (1994) showed that plant resistance to aphids and possibly BYDV transmission is associated with an increase in the time required by aphids to penetrate the phloem. The results in this experiment did not agree with such reports (Table 1). It was suggested that there could be resistance against aphids in some grasses making them difficult to be infected with BYDV. The results obtained in this study did not show difficulty in getting any of the varieties infected with the virus. ELISA test results showed that the virus infects all the varieties studied and in general, when Oats, all "susceptible" varieties and all "resistant" varieties were compared, it was observed that the "resistant" varieties had lower but not significantly different infection levels in comparison to the others at all the inoculation access 
feeding periods used (Fig. 1). This indicates that host effect on feeding period cannot adequately explain the mechanism behind such resistance. Tolerance seems unlikely because even with the apparently resistant varieties, some plants showed symptoms and these symptoms were as strong as those in the "susceptible" varieties. Also ELISA titre values indicated that there was no possibility of tolerance in these fortuitously discovered spring sown "resistant" varieties of spring barley. In autumn sown barley, tolerance is reported to be governed by a single major gene of Ethiopian origin designated as Yd2 gene (Rassmusson and Schaller, 1959).

\section{Conclusion}

The mechanism governing BYDV resistance in these varieties of spring barley studied is not well explained by a host plant effect on feeding period. Work is continuing at Rothamsted on the other aspects of aphid feeding behaviour such as rate of probing, depth of probing etc. ELISA results indicated the unlikeliness of tolerance.

\section{Acknowledgements}

The first author was an ODASS Scholar. IACR - Rothamsted receives grant-aided support from the Biotechnology and Biological Sciences Research Council of the United Kingdom. The New Farm Crops Limited Lincolnshire, U.K. (a subsidiary of Ciba-Geigy) which provided the seeds used in this study is also acknowledged.

\section{Literature}

A'Brook, J. (1974): Barley yellow dwarf virus: What sort of a problem? Annals of Applied Biology 77, 92-96. A' Brook, J. and Dewar, A. M. (1980): Barley yellow dwarf virus infectivity of alate aphid vectors in West Wales. Annals of Applied Biology 96, 51-58.

Doodson, J. K. and Saunders P. J. W. (1970): Some effects of barley yellow dwarf virus in spring and winter cereals in glasshouse trials. Annals of Applied Biology 65, 317-325.

Haniotakis, G. E. and Lange, W. H. (1974): Beet yellows virus resistance in sugar beets; Mechanisms of resistance. Journal of Economic Entomology 67, 25-28.

Irwin, M. E. and Thresh, J. M. (1990): Epidemiology of barley yellow dwarf: A Study in ecological complexity. Annual Review of Phytopathology 28, 393-424.

Lister, R. M. and Rochow, F. (1979): Detection of barley yellow dwarf virus by enzyme linked immunosorbent assay. Phytopathology 69, 649-653.

Lister, R. M. and Ranieri, R. (1995): Distribution and economic importance of barley yellow dwarf. In: Barley Yellow Dwarf. 40 Years of Progress (eds): D’ Arcy, C. and P. Burnnett). A. P. S. Press Minnesota. pp. 29-54.

Lowles, A. J., Harrington R., Tatchell, G. M. and Clarke, S. J. (1996): The effect of temperature and inoculation access period on the transmission of barley yellow dwarf virus by Rhopalosiphum padi and Sitobion avenae. Annals of Applied Biology 128, 45-53.

Oswald, J. W. and Houston B. R. (1953): The yellow dwarf virus disease of cereal crops. Phytopathology 43, $128-136$. 
Plumb, R. T. (1977): Grass as a reservoir of cereal viruses. Annals of Phytopathology 9, 361-365.

Rassmusson, D. C and Schaller, C. W. (1959): The inheritance of resistance in barley to yellow dwarf virus. Agronomy Journal 51, 661-664.

Rochow, W. F. (1970): Barley yellow dwarf virus. Desc. of Plant Viruses CMI/AAB 32.

Smith H. C. (1993): Control of barley yellow dwarf virus in cereals. New Zealand Journal of Agricultural Research 6, 229-234.

Tjallingi, W. F. (1994): Sieve element acceptance by aphids. European Journal of Entomology 91, 47-52.

Ullman, D. E., Qualset, C. O. and McLean, D. L. (1988): Feeding response of Rhopalosiphum padi to barley yellow dwarf virus in resistant and susceptible barley varieties. Environmental Entomology 17, 988-991. 